\title{
Retraction Note to: An Introduction to Mental Language in Late Medieval Philosophy
}

\author{
Magali Roques and Jenny Pelletier
}

\section{Retraction Note to:}

Chapter 1 In: J. Pelletier, M. Roques (eds.), The Language of Thought in Late Medieval Philosophy, Historical-Analytical Studies on Nature, Mind and Action 5, https://doi.org/10.1007/ 978-3-319-66634-1_1

The authors have retracted this chapter [1] because of significant textual overlap with a number of sources, including:

Biard 2010 = Joël Biard, "Nominalism in the Late Middle Ages," in The Cambridge History of Medieval Philosophy, vol. II, edited by Robert Pasnau and Christina van Dyke (Cambridge: Cambridge University Press 2010), 661-673.

Cross 2014 = Richard Cross, Duns Scotus's Theory of Cognition (Oxford: Oxford University Press, 2014).

\footnotetext{
The retracted version of this chapter can be found at https://doi.org/10.1007/978-3-319-66634-1_1 
Brower-Toland 2014 = Susan Brower-Toland, "William Ockham on the Scope and Limits of Consciousness," Vivarium 52, no. 3/4 (2014): 197-219.

Brower-Toland 2015 = Susan Brower-Toland, "How Chatton Changed Ockham's Mind: William Ockham and Walter Chatton on Objects and Acts of Judgment," in Intentionality, Cognition, and Mental Representation in Medieval Philosophy, edited by Gyula Klima (New York: Fordham University Press, 2015), 204-234.

Dutilh Novaes 2007 = Catarina Dutilh Novaes, Formalizing Medieval Logical Theories: Suppositio, Consequentiae, and Obligationes (Cham: Springer, 2007).

Friedman 2003 = Russell L. Friedman, "James of Metz," in A Companion to Philosophy in the Middle Ages, edited by Jorge J. E. Gracia and Timothy B. Noone (Malden: Blackwell, 2003), 330-331.

Friedman 2015 = Russell L. Friedman, "Act, Species, and Appearance: Peter Auriol on Intellectual Cognition and Consciousness," in Intentionality, Cognition, and Mental Representation in Medieval Philosophy, edited by Gyula Klima (New York: Fordham University Press, 2015), 141-165.

Friedman and Pelletier 2014 = Russell L. Friedman and Jenny Pelletier, "Mental Words and Mental Langauge in the Later Middle Ages," in Sourcebook for the History of the Philosophy of Mind:Philosophical Psychology from Plato to Kant, edited by Simo Knuuttila and Juha Sihvola (Dordrecht: Springer 2014), 379-400.

Gelfert 2015 = Axel Gelfert, "Inner Speech, Natural Language, and the Modularity of the Mind," in Kairos. Journal of Philosophy \& Science 14 (2015): 7-29.

Hochschild 2015 = Joshua P. Hochschild, "Mental Language in Aquinas?" in Intentionality, Cognition, and Mental Representation in Medieval Philosophy, edited by Gyula Klima (New York: Fordham University Press, 2015), 29-45.

King 2015 = Peter King, "Thinking About Things: Singular Thought in the Middle Ages," in Intentionality, Cognition, and Mental Representation in Medieval Philosophy, edited by Gyula Klima (New York: Fordham University Press, 2015) 104-121.

Klima 2008 = Klima, Gyula, John Buridan (Oxford: Oxford University Press, 2008).

Klima 2015 = Gyula Klima (ed.), Intentionality, Cognition, and Mental Representation in Medieval Philosophy, edited by Gyula Klima (New York: Fordham University Press, 2015). 
Klima 2015a = Gyula Klima, "Introduction: Intentionality, Cognition, and Mental Representation in Medieval Philosophy," in Intentionality, Cognition, and Mental Representation in Medieval Philosophy, edited by Gyula Klima (New York: Fordham University Press, 2015), 1-8.

Knuuttila and Sihvola 2014 = Simo Knuuttila and Juha Sihvola (eds.), Sourcebook for the History of the Philosophy of Mind: Philosophical Psychology from Plato to Kant (Dordrecht: Springer 2014).

Normore 1990 = Calvin G. Normore, "Ockham on Mental Language," in Historical Foundations of Cognitive Science, edited by J-C. Smith (Dordrecht Kluwer, 1991), 53-70.

Normore 1997 = Calvin G. Normore, "Material Supposition and the Mental Language of Ockham's Summa Logicae,” Topoi 16 (1997): 27-33.

Normore 1999 = "Some Aspects of Ockham's Logic," in The Cambridge Companion to Ockham, edited by Paul Vincent Spade (Cambridge: Cambridge University Press, 1999), 31-52.

Normore 2009 = Calvin Normore, "The End of Mental Language," in Le langage mental du moyen âge à l'âge classique, edited by Joël Biard (Louvain: Éditions Peeters, 2009), 293-306.

Normore 2010 = Calvin Normore, "Primitive Intentionality and Reduced Intentionality: Ockham's Legacy," Quaestio 10 (2010): 255-266.

Normore 2011 = Externalism, "Singular Thought and Nominalist Ontology," in The Demonic Temptations of Medieval Nominalism, edited by Gyula Klima and Alexander W. Hall (Newcastle upon Tyne: Cambridge Scholars Publishing, 2011), 137-148.

Nuchelmans 1992/1996 = Gabriel Nuchelmans, "Some Remarks on the Role of Mental Sentences in Medieval Semantics," Histoire Épistémologie Langage 14, no. 2 (1992), 69-80, reprinted in Studies on the History of Logic and Semantics, 12th-17th Centuries, edited by E. P. Box (Aldershot: Ashgate, 1996).

Panaccio 2003 = Claude Panaccio, "Ockham and Locke on Mental Language," in The Medieval Heritage in Early Modern Metaphysics and Modal Theory, 14001700, edited by Russell L. Friedman and Lauge O. Nielsen (Dordrecht: Springer, 2003), 37-51.

Panaccio 2013 = Claude Panaccio, "Ockham and Buridan on Simple Supposition," Vivarium 51, no. 1 (2013): 371-384. 
Read 2015 = Stephen Read, "Concepts and Meaning in Medieval Philosophy," in Intentionality, Cognition, and Mental Representation in Medieval Philosophy, edited by Gyula Klima (New York: Fordham University Press, 2015), 9-28.

Schierbaum 2014 =Sonja Schierbaum, Ockham's Assumption of Mental Speech: Thinking in a World of Particulars (Leiden: Brill, 2014).

Toivanen and Yrjönsuuri 2014 = Juhana Toivanen and Mikko Yrjönsuuri, "Medieval Theories," in Sourcebook for the History of the Philosophy of Mind: Philosophical Psychology from Plato to Kant, edited by Simo Knuuttila and Juha Sihvola (Dordrecht: Springer 2014), 429-446.

van der Lecq 2000 = Ria van der Lecq, "Mental Language: A Key to the Understanding of Buridan's Semantics," https://www.academia.edu/42930930/ Mental_Language_A_key_to_the_understanding_of_Buridans_semantics

All authors agree to this retraction. Magali Roques accepts responsibility for introducing this overlap into the text.

[1] Roques M., Pelletier J. (2017) An Introduction to Mental Language in Late Medieval Philosophy. In: Pelletier J., Roques M. (eds) The Language of Thought in Late Medieval Philosophy. Historical-Analytical Studies on Nature, Mind and Action, vol 5. Springer, Cham.

https://doi.org/10.1007/978-3-319-66634-1_1 